CZU: 821.135.1-94(478).09

https://doi.org/10.52505/lecturi.2021.05.23

\title{
JURNALELE LUI VLADIMIR BEȘLEAGĂ - O ARS COMBINATORIA SUI-GENERIS
}

\author{
Inga SOROCEAN \\ Institutul de Filologie Română „Bogdan Petriceicu-Hasdeu”, Chișinău
}

Rezumat. În ultimele decenii, poetica jurnalului intim este supusă unui proces de reconfigurare a propriei esențe. Clauzele acestui tip de scriitură sunt din ce în ce mai des sublimate, textul confesiv integrează genuri liminare, căpătând forme hibride. Astfel, autorii de jurnal preferă să experimenteze nu doar cu personajul marcat de o identitate proteică, dar și cu tehnicile diaristice care devin o ars combinatoria, o orchestrație personalizată deseori prin recursul la artele vizuale (fotografie, grafică). Jurnalele publicate de Vladimir Beșleagă în ultima perioadă (2020-2021) se înscriu perfect în acest model diaristic. Scriitorul își asumă rolul unui ,alt fel” de diarist, care reușește să mixeze observații zilnice, reflecții asupra datului ontologic, anecdote, exerciții de versificație, crochiuri și imagini simbolice, prin care asigură o coerență tematică și stilistică inconfundabilă.

Cuvinte-cheie: jurnal intim, clauze, diarist, ars combinatoria, tehnici diaristice, arte vizuale.

Abstract. The diary poetics has undergone through a process of essence reconfiguration in recent decades. The clauses of this diary form are often sublimated as confessional text integrates liminal genres, acquiring hybrid forms. Journal's authors prefer to experiment both with the character marked by a variable identity and the diaristic techniques. This approach becomes an ars combinatoria with an orchestration often customized through the use of visual arts (photography, graphics). Vladimir Beșleagă recent journals (2020-2021) fit perfectly into this diaristic model. The author assumes the role of a ,different kind" of diarist, who manages to mix daily observations, reflections on ontological data, anecdotes, versification exercises, sketches and symbolic images, ensuring an unmistakable thematic and stylistic coherence.

Keywords: intimate diary, clauses, diarist, ars combinatoria, diaristic techniques, visual arts.

Structură deschisă prin excelență, deseori concurând cu opera de ficțiune a scriitorilor, jurnalul intim ne oferă, în ultimele decenii, un spectacol al căutării sinelui și al raportării la lume, dar și al individualizării scriiturii diaristice, prin 
recursul la tehnici și procedee insolite, astfel că arhitectura textului iese în primplanul structurii de existență a celui care scrie. În acest context al căutărilor de noi formule, poetica jurnalului intim este supusă unui proces de reconfigurare a propriei esențe. Clauzele acestui tip de scriitură (calendaritatea, autenticitatea, fragmentarismul, sinceritatea, simultaneitatea, confidențialitatea) sunt din ce în ce mai des sublimate, textul confesiv capătă forme hibride (metajurnale, pseudojurnale etc.) în care sesizăm, dincolo de liniile unui (auto)portret, o strategie proiectivă a diaristului din care derivă existența unei preocupări estetice evidente. Tehnicile diaristice devin o ars combinatoria (Dinu, 2012, p. 28), o orchestrație personalizată deseori prin recursul la artele vizuale (fotografie, grafică, desen), așa cum se întâmplă, de exemplu, în cazul fragmentelor de jurnal intelectual din volumul lui Gheorghe Crăciun „Mecanica fluidului”, apărut la Editura Cartier în 2003, reunite sub genericul Grandangular (1), (2), (3) etc., termen preluat din limbajul tehnic al artei fotografice. Această alternanță a notelor zilnice cu bucăți de proză, pasaje eseistice, fișe de lectură, desene și fotografii ale autorului, relevă o structură biplană care amintește de tehnica prozatorului din romanul „Compunere cu paralele inegale” (1988). Jurnalul, din aceasta perspectivă, se transformă într-un exercițiu de componistică, ieșind în afara normei speciei.

Jurnalele publicate de scriitorul basarabean Vladimir Beșleagă în perioada 2020-2021 - „Reflecții / instantanee. Jurnal de poet”, „Ochii Stelianei. Jurnal liric”, „Nugae sau cartea nimicurilor (pdeudo-jurnal)”, Editura Epigraf, 2020, „Jurnal”, Editura Polisalm, 2021 - se înscriu perfect în acest model diaristic. Autorul își asumă rolul unui ,alt fel” de diarist, care reușește să mixeze observații zilnice, reflecții asupra datului ontologic, anecdote, exerciții de versificație, integrând crochiuri și imagini/desene simbolice prin care asigură o coerență tematică și stilistică inconfundabilă.

„Jurnal”-ul apărut în 2021 are o arhitectonică impresionantă, conținând 4 părți: 1. Sfidând adolescența (jurnal în jurnal), 2. Addenda I. Jurnal de studenție; 3. Addenda II. Amintiri pestrițe; 4. Addenda III. Jurnalul unui deceniu. În prima parte, clauza calendarității este respectată, însemnările zilnice se fac cu regularitate, începând cu data de 1 ianuarie 2000 până în ziua de 8 mai 2000. Dimensiunii psihologice, dorinței de exhibare a eului profund îi corespunde, indubitabil, o dimensiune estetică, relevând aspirația diaristului Vladimir Beșleagă de a face literatură prin valorificarea retrospectivă a propriei existențe. E un jurnal al scrierii „în ramă”, al rememorării și analizei propriului trecut, cu cel puțin două nivele: cel al scriiturii, raportat la timpul prezent, și cel al rememorării orientat spre amintirile din adolescentă. Încă de la început, diaristul ne atenționează, prin figurile retorice care inundă pagina, asupra unor dileme și căutări interioare, semn că cel care scrie 
își va fixa privirea, în primul rând, asupra interiorității: „... ce sunt eu dacă nu un rătăcit?... un mizerabil rătăcit... iată vine sfârșitul zilelor mele...într-o zi: gata, m-am dus... şi atunci cine va răspunde pentru mine: de ce-am trăit? La ce bun? Ce-am făcut pe lumea asta? Am încălzit pe cineva? [...] Doamne, oare Tu ai îngăduit să mă rătăcesc?" (Beșleagă, 2021, p. 9). În acest periplu al autocunoașterii, personajul, aflat la vârsta venerabilă a totalizărilor, se ciocnește de propria alteritate care îi clatină certitudinea cunoașterii totale: „... mă întorc la mine însumi și mă cercetez: sunt eu oare cu adevărat acela care mă cred că sunt? Sunt eu oare așa cum mă știu că sunt? Cum oare voi putea ști cine și cum sunt cu adevărat, iară nu mă înșel în marea mea dragoste pentru mine însumi?..." (Beşleagă, 2021, p. 10).

Lamentațiile și neliniștile spiritului, generate de reflecțiile vizavi de ratarea autocunoașterii și zădărnicia existenței umane care creionează substratul filozofic al jurnalului, constituie, de fapt, o pregătire pentru intrarea diaristului în marea aventură a scriiturii. Fiind „un jurnal în jurnal”, vocii din prezent îi corespunde un destinatar din trecut, un eu de la 18 ani, introdus în scenă printr-un exerciţiu oniric de ficționalizare. Miracolul începe în spațiul oniric, acolo unde are loc întâlnirea cu sine. Visându-se în rolul de hingher care merge să prindă câinii vagabonzi de pe străzile capitalei, personajul se pomenește față în față cu un tânăr care seamănă leit cu propria imagine dintr-o fotografie de tinerețe. O întâlnire à la Borges (amintind de povestirea „Celălalt” din volumul „Cartea de nisip”) dintre eu: ,bătrânul ramolit și ratat, și el - „tânărul sănătos și plin de viață” (Beșleagă, 2021, p. 48), la o distanță temporală de 50 de ani, întâlnire care se va repeta zi de zi, prin relectura carnetelor și a jurnalelor de demult, cei doi întreținând dialoguri intelectuale uneori dominant conciliante, alteori polemice: „IImi placi băiete... Se prefigurează un dialog sărat. Așa da, tu - de partea cealaltă a Timpului, eu - de partea aceasta. Conversăm/ discutăm peste cursul lui... »./ «Nu contează. Important e să ne vedem. Să ne privim în față. Dacă timpul e obscur, noi să fim clari - iluminați...»” (Beșleagă, 2021, p. 54).

Discuțiile de la primul nivelul al textului se axează pe diverse teme: meseria scrisului, dramele timpului istoric (foametea, seceta, tifosul) și cele personale (condamnarea tatălui), primele încercări de versificare (unele poezii sunt rescrise integral) și de a compune proză, prima iubire, activitățile școlărești etc., toate cu scopul de înțelegere a sinelui, după cum mărturisește însuși autorul: „crezi, pentru ce am coborât eu în adâncul memoriei? ca să te judec? să te condamn? nu! pentru ca să te înțeleg, să te cunosc mai bine” (Beșleagă, 2021, p. 190).

La celălalt nivel al scriiturii vor fi inserate/ recopiate notele din tinerețe. Avem deci un caz de ,scriitură multiplă”, cu două voci cărora le corespund două modalități 180 
temporale: un timp recapitulativ (un trecut actualizat prin scris și adus în prim-plan de însemnările din anii de tinerețe), și un timp paralel, al prezentului convențional (Mihăieș, 1995, p. 245-247). După alternanța amețitoare de replici dintre cele două ipostaze (eu/tu) ale personajului, intervin momente de (auto)analiză și luciditate ancorate în prezent. Momentele au un efect de stop-cadru în care, prin reflecție, se ajunge la reîntregirea imaginii scriitorului: „... prostii, naivități... dar ce să te faci dacă... m-am contaminat de acestă boală? [scrisul]..., abia după treizeci am conștientizat, am descoperit că apucând calea scrisului, mi-am deviat existența... or, scriitura mi-a modificat radical felul de a trăi, a gândi, a simți, a reacționa, a înțelege lucrurile și oamenii..." (Beșleagă, 2021, p. 62).

Indiscutabil, această tehnică diaristică relevă virtuozitățile de prozator ale lui Vladimir Beșleagă, apetența clară pentru structura dialogică a discursului. E suficient să amintim de coborârile în subteranele conștiinței ale lui Isai, din romanul „Zbor frânt”, sau ale lui Filimon, din „Viața și moartea nefericitului Filimon”, coborâri susținute de „amestecul de «glasuri»" (Burlacu, 2009, p. 71), de înlocuirea discursului monologic cu structura dialogică, astfel încât prezentul trecutul și viitorul se întrepătrund și se permanentizează hic et nunc (Burlacu, 2009, p. 10).

Când aventura dialogică din prima parte a „Jurnal"'-ului se termină, diaristul face totalurile și încheagă un ,portret psiho/socio/fiziologic” al tânărului în care se regăsesc trăsături precum: perspicacitatea, inteligența, îndărătnicia, imaginația, umorul, sentimentul tragicului, analitismul (Beșleagă, 2021, p. 215-221). Este momentul în care perspectiva dialogică cedează locul rescrierii notelor din perioada 1 ianuarie 1950-9 iunie 1950.

Celelalte părți ale jurnalului sunt mai puțin spectaculoase din punctul de vedere al tehnicii diaristice, fixând impresii, amintiri din alte perioade: anii de studenție marcați de încercarea de afirmare profesională, de studiile de doctorat și întemeierea unei familii (Addenda I, Addenda II), experiența paternității și cea de șomer, laboratorul de lectură și scriere („Nepotul”) din perioada 1956 - 1965, memorabilă mai ales prin aura suferinței provocată de boala incurabilă a mamei, dar și prin atitudinea critică față de lumea exterioară dominată de ,parvenitism (arivism), autoadmirare, ambiție, impertinență, fariseism, vânzare de frate..." (Beșleagă, 2021, p. 391) (Addenda III). Totuși găsim, în aceste pagini, seva definitorie pentru viziunea diaristului din celelalte jurnale publicate în 2020, viziune care integrează arta combinatorie prin care se valorifică vizualul/picturalul, auditivul/muzicalul, poezia/liricul, narativul/proza. Secvențele surprind marea obsesie a lui V1. Beșleagă pentru artele vizuale (fotografia, desenul/pictura) și pentru cele auditive (muzica), semn că avem de-a face cu o strategie asumată de către autorul-diarist-pictor- 
muzician-poet-prozator: „Cuvântul dă naștere imaginii sau-invers? De la imagine pornind, găsești cuvântul care se potrivește și prin el fixezi tabloul. Ori - poate aici e cea mai strânsă legătură dialectică? Cuvântul și imaginea întâlnindu-se ajung să se adâncească reciproc pe cât este posibil...” (Beșleagă, 2021, p. 355); „, deși lumea știe că am debutat cu povestiri pentru copii, poezia continuă să trăiască in sufletul meu ca cea mai veche și mai mândră locatară și când se întâmplă să mă simt în al șaptelea cer, gândurile toate și simțămintele, scăpărările minții și bătăile inimii se revarsă de la sine în versuri care îmi sună și răsună mereu în urechi...। Orice și oricum o să fie, dar simt că fără a scrie versuri n-o să pot niciodată, nu..." (Beșleagă, 2021, p. 356); „Literatura artistică [...] este, aș zice, mai curând un desen în acuarelă și încă unul de cea mai fină speță. Așa încât... Da, acum îmi dau seama că trebuie să învăț a picta... Or, până acum mă orientam în lucrul meu, în fond, spre a surprinde muzicalitatea (melodia) în scris. Adică, compunând o frază, o citeam și o ascultam eu însumi, ca să mă conving că sună frumos. Acum, fiind acesta o etapă trecută, voi să mă perfecționez și în altă direcție - cea a picturalului, adică să văd cum arată cele ieșite de sub pana mea... Desigur fără să-mi scape din vedere celelalte componente esențiale ale operei: compoziția etc...." (Beșleagă, 2021, p. 369)

În „Ochii Stelianei. Jurnal liric”, carte dedicată poetei Steliana Grama, arta combinatorie relevă apetența pentru poeme, confesiune, dialog, aforisme, reunite sub cupola temei vieții și morții, a existenței marcate de zădărnicie și efemeritate. Poezia devine o lentilă sub care realitatea, marea trecere, capătă contururi dramatice, convertindu-se în mari revelații: ,... din cărțile lumii-am citit destule - / din ideile lumii-am aflat destule / acum citesc tot-mai greu / acum cuget - tot mai anevoie / dar năravul - nu l-am pierdut / se ține de mine / se ține de mine scai: / vreau să citesc / vreau să cuget / și-atunci - ce mă fac? / să închid ochii înainte de vreme? / evrica! Am găsit: / voi citi / cartea propriului trup / voi vântura / gândurile propriei minți! / să știi că e / in-te-re-sant... / ba chiar / cap-ti-vant! / și eu - prostul - / alergam cu sufletul la gură / după tot alte / și alte cărți / și eu-prostul / credeam că numai / ideile altora / valorează / acum târziu / mi-am dat seama că toate se află / în mine însumi: și cărțile mari / ale lumii / și ideile înțelepte / ale omenirii... / târziu / am făcut această / minunată descopreire!...” (Beșleagă, 2020, p. 78)".

Dacă în acest jurnal putem vorbi despre o viziune diaristică prin care poeticul adună, într-o formulă plină de sensibilitate și de simţul tragicului, sensuri ,constituite muzical" și ,narativ” (Corcinschi, 2020, p. 146-152), în celelalte 2 jurnale la care vom face referință, ecuației diaristice i se vor adăuga și sensurile constituite vizual.

În „Reflecții/Instantanee. Jurnal de poet” diaristul are o predispoziţie spre ludic, spre jocul lingvistic/sonor/poetic/lalic și calambur, fiind extrem de atent 
la grafica textului. La un moment, acțiunea de fragmentare este văzută de autor ca „viciu”, „semn al degradării conștiinței”, în detrimentul apetitului pentru construirea sistemelor complexe, a gândirii de amploare oglindită în fraza „largă, stufoasă, complicată” care, i se pare, acum, susceptibilă de artificiu: ,Se pare că m-am țicnit pe chestia ... calambururilor, mai exact, a etimologiilor, analogiilor, omo- și ahti-foniilor (desigur, în raport cu sensurile), ceea ce nu vrea decât să dovedească în mod clar că mă detaliez/fragmentarizez/așchiez... măruntez! Să fie aceasta un semn al degradării sistemului nervos? alias a conștiinței care se ... destramă? Și nu mai e în stare de reflecții/speculațiilaventuri ale gândirii de o mare amploare?" (Beșleagă, 2020, p. 238) . Această incertitudine, amestecată cu (auto)ironie, trădează ,poza”, plăcerea scriitorului de a căuta muzicalul, sonorităţile inedite.

În aceeași ordine de idei, pseudo-jurnalul „Nugae sau Cartea nimicurilor”, ilustrat cu desenele Teodorei Vasiliu, se transformă dintr-un monolog ideatic al spunerii într-un dialog textual-imagistic, într-un exercițiu scriptic prins în plasa (auto)ironiei și a ludicului. Fragmentele lirice, la prima vedere frivole, lipsite de miză, eșantioane ale nimicurilor zilnice exterioare, fuzionează și, printr-o impresionantă tehnică a privirii prin ricoșeu, se îndreaptă dinspre identitatea lumii spre identitatea celui care scrie. Exercițiile poetice au același generic - NUGA - termen menit, în teoria literară antică, să servească la departajarea genurilor poetice minore de cele majore. În jurnalul lui Vladimir Beșleagă, acesta este indiciu al inspirației din mărunțișurile vieții, din aspectele așa-zis „minore”, care îi alimentează scrisul și îl adâncesc pe diarist în reflecție, situație surprinsă în „,NUGA $\boldsymbol{c u}$ două... finaluri... (din memorie)": „Mi-s atâta de... străine/și atâta de departe/și lumea care-a fost/ și viața ce-am trăit - / că nu-mi rămâne decât / să mai plătesc c-o moarte / Deaceea sunt / pe zi ce trecel Tot mai trist... / Cel de-al doilea final:/ De aceea tot mai des / Îmi vine să râd! / (De ce așa? Nu știu!)" (Beșleagă, 2020, p. 68). Cele două coordonate ale ființării scriitorului în lume - râsul și plânsul - sunt redate, în acest pseudo-jurnal, prin îmbinarea viziunii comico-ironice asupra lumii/ propriei identități, dar și prin cumpănirea profund asumată a omului trecut prin viață, combinată cu reprezentarea grafică a viziunii inocente și aerate despre lume, oglindită în desenele tinerei pictorițe.

În concluzie, arta combinatorie din jurnalele analizate, fie că se referă la tehnica diaristică axată pe structura dialogică a discursului din ,Jurnal” (2021), sau la îmbinarea sensurilor constituite vizual-narativ-liric-muzical din celelalte trei jurnale, este o marcă stilistică sui-generis a scriiturii lui Vladimir Beșleagă, scriitorul neobosit care este mereu în căutarea trăirii autentice, a cuvântului potrivit care exprimă adevărul despre sine, despre lume, despre literatură/artă, dar și în căutarea unei stilistici proprii care să asigure o funcţionare constantă a mecanismului scriiturii. 


\section{Referințe bibliografice:}

1. BEȘLEAGĂ, Vladimir, NUGAE sau CARTEA NIMICURILOR (pseudo-JURNAL). Chișinău: Epigraf, 2020.

2. BEȘLEAGĂ, Vladimir, Ochii Stelianei. Jurnal liric. Chișinău: Epigraf, 2020.

3. BEȘLEAGĂ, Vladimir. Jurnal. Chișinău: Polisalm, 2021.

4. BEȘLEAGĂ, Vladimir. Reflecții / instantanee. Jurnal de poet. Chișinău: Epigraf, 2020.

5. BURLACU, Alexandru. Vladimir Beșleagă, po(i)etica romanului. Chișinău: Gunivas, 2009.

6. CORCINSCHI, Nina. Jurnalul liric „Ochii Stelianei”. În: Ochii Stelianei. Jurnal liric. Chișinău: Epigraf, 2020, p. 143-159.

7. DINU, Adela. Diaristica feminină românescă. Cluj-Napoca: Eikon, 2012.

8. MIHĂIEȘ, Mircea. Cărțile crude. Jurnalul intim și sinuciderea. Timișoara: Amarcord, 1995.

Notă: Articolul a fost realizat în cadrul proiectului de cercetare 20.80009.1606.03 Contexte socioculturale autohtone şi interconexiuni europene $\hat{\imath}$ creaţia populară şi literatura cultă din Basarabia (sec. XIX până în prezent), Institutul de Filologie Română «B. P.-Hasdeu” al MEC. 